\title{
CAÇA E PRESERVAÇÃo DA VIDA SELVAGEM NA ÁFRICA COLONIAL
}

\author{
Sílvio Marcus de Souza Correa*
}

\begin{abstract}
Resumo: No início do século XX, com as descobertas científicas dos agentes etiológicos e dos vetores de certas doenças tropicais, algumas medidas de saneamento na África colonial se traduziram em abate indiscriminado de animais selvagens. Em 1910, uma matança ocorrida na África Oriental Alemã (atual Tanzânia) desencadeou um intenso debate sobre a proteção da vida selvagem. Nas décadas seguintes, outras matanças foram realizadas em colônias ou protetorados britânicos na África. A partir dos meados do século XX, várias regiões da África Oriental Portuguesa (atual Moçambique) foram zonas de ação da Missão de Combate à Tripanossomíase (MCT) e de suas Brigadas de Caça. Todavia, o abate indiscriminado da "caça grossa" foi alvo de críticas de alguns médicos veterinários que trabalhavam para a MCT. O debate sobre as matanças teve também a participação de caçadores amadores. Alguns defensores da caça esportiva foram protagonistas de uma série de ações preservacionistas. Esse incipiente preservacionismo não foi anticolonialista, mas serviu para orientar os primeiros projetos de parques de preservação e reservas naturais na África.
\end{abstract}

Palavras-chave: Caça. Preservação. Vida selvagem. Doenças tropicais. África colonial.

Abstract: At the beginning of the XX century, with the scientific discoveries of the
etiologic agents and vectors of certain tropical diseases, some measures of sanitation
in colonial Africa were implemented as indiscriminate cull of wild animals. In 1910,
a killing that occurred in the German Oriental Africa, (current Tanzania) initiated an
intense debate about the protection of wild life. In the following decades, other killings
happened in colonies or British protectorates in Africa. From mid 20th. century, many
regions in Portuguese Oriental Africa (current Mozambique) were zones of action for
the Combat Mission to Tripanossomiase (MCT) and their hunting brigades. However
the indiscriminate cull of wild animals, was the target of criticism from some
veterinarian doctors that worked from MCT. Some amateur hunters also
participated in this debate about the killings. Some defenders of the sport

* Professor de História da África na Universidade Federal de Santa Catarina - UFSC.

E-mail: silvio.correa@pq.cnpq.br 
hunting were protagonists of a series of preservationist actions. This incipient preservationism was not anti-colonial, but served to orientate the first projects of preservation parks and natural reserves in Africa.

Keywords: Hunting. Preservation. Wild Life. Tropical Diseases. Colonial Africa.

\section{INTRODUÇÃO}

Em diferentes espaços da África colonial se desenvolveram práticas esportivas. Algumas delas, como o futebol, tiveram nas cidades coloniais ou na sua periferia um espaço social propício não apenas para a sua reprodução entre europeus como também para sua popularização entre africanos. Outros esportes, como a caça, se desenvolveram às margens dos impérios, nos confins dos territórios coloniais. ${ }^{2}$ Isso não significa que foram esportes de menor importância no contexto colonial.

A caça esportiva fez parte de um habitus em toda a África colonial. Mas ela não foi a única modalidade. Outras formas de caça eram praticadas por várias comunidades africanas. Havia ainda a famigerada caça comercial que fornecia ao mercado marfim, peles, plumas, etc. Além dos tradicionais mercados consumidores do Oriente, havia a expansão do mercado das sociedades industriais do Ocidente. Bolas de bilhar, teclas de piano, armação de óculos, vestuário e acessórios como chapéus femininos e vários outros produtos metropolitanos tinham como matéria-prima ou ornamento, marfim, peles e plumas de animais selvagens do continente africano. Instituições científicas da Europa e dos EUA, como, por exemplo, museus de história natural, institutos de zoologia e parques zoológicos, fomentaram, igualmente, o mercado de animais selvagens.

O colonialismo foi um período sem precedentes no que tange ao extermínio de muitas espécies de animais selvagens e à redução drástica do número de seus exemplares em várias regiões africanas e, indubitavelmente, a caça foi um dos seus principais fatores. A caça ao elefante foi, sem dúvida, a mais emblemática. ${ }^{3}$ Ela provocou um decréscimo vertiginoso dos paquidermes em várias colônias de diferentes impérios, o que suscitou uma mobilização preservacionista trans-imperial tanto por parte de naturalistas quanto amadores da caça esportiva.

A caça esportiva produziu, paradoxalmente, uma consciência preservacionista tanto nas metrópoles quanto nas colônias. Associações ou clubes de caçadores fizeram propostas de leis de proteção à vida selvagem, inclusive de criação de parques e reservas. Nesse sentido, alguns amadores da 
caça esportiva foram protagonistas do preservacionismo, mesmo que isso não significasse, necessariamente, uma crítica ao sistema colonial.

O presente artigo trata do duplo engajamento de alguns amadores da caça esportiva; primeiro, contra um discurso político-científico de extermínio dos animais de "caça grossa" (Big Game) e, em segundo, em prol de parques e reservas de proteção à vida selvagem. Destaca-se, igualmente, a simultaneidade dessas experiências na África austral e oriental sobre domínio britânico e alemão e sua defasagem com relação à "África portuguesa", especialmente Angola e Moçambique. Com isso, busca-se superar o que pode ser chamado de "luso-tropicalismo metodológico" por meio de uma análise histórica da circulação de práticas esportivas entre colônias de diferentes impérios e não simplesmente entre colônias do mundo luso-tropical. É nesta circulação de experiências entre metrópoles e colônias de vários impérios que se insere o preservacionismo de alguns caçadores desportistas.

\section{A CAÇA ESPORTIVA: HABITUS E EMULAÇÃO SOCIAL}

O habitus da caça esportiva na África colonial era, inicialmente, apanágio de poucos aristocratas a serviço imperial ou de visita às colônias. Não tardou, porém, para ocorrer uma diversificação do grupo de amadores da caça esportiva. ${ }^{4}$ Àquela minoria branca pertencente a uma nobreza europeia somaram-se alguns funcionários ou comerciantes de origem burguesa e muitos colonos plebeus. Se dândis reproduziam seu habitus aristocrático nas colônias africanas, burgueses e plebeus praticavam a caça esportiva como forma de emulação. ${ }^{5}$ Isso explica em parte o sucesso que obteve a caça esportiva na África colonial. Ela passou a fazer parte de um habitus colonial e um apanágio do poder branco no mundo colonial.

$\mathrm{Na}$ África sob domínio alemão, a caça esportiva foi ainda praticada pelos soldados e oficiais da Schutztruppe. ${ }^{6} \mathrm{Na}$ África austral, os bôeres praticavam não apenas a caça esportiva, mas também a "unsportsmanlike shooting". ${ }^{7} \mathrm{Na}$ África sob domínio britânico e sob domínio português, oficiais e soldados também caçavam. ${ }^{8}$ Em Moçambique, alguns ex-combatentes continuaram a praticá-la, mesmo assumindo encargos oficiais em serviços de preservação à vida selvagem, como Alfredo Rodrigues, encarregado do Parque da Gorongosa.

Nas primeiras décadas do século XX, os reclames de material para caça ou safáris em jornais e magazines, tanto das metrópoles quanto das colônias, acusam a importância de tais práticas na África colonial, especialmente na sua parte austral e oriental. Também o mercado editorial promovia uma copiosa literatura de caça. ${ }^{9}$ Nas páginas de jornais e revistas ilustradas pululavam matérias e fotos de caçadas. Esses periódicos fornecem ao historiador hodierno informações sobre algumas polêmicas relacionadas à caça durante o período 
colonial. Entre elas, o extermínio da 'caça grossa' proposto por alguns em nome da ciência e posto em prática por outros a serviço imperial em certas regiões da África colonial.

\section{MATANÇA DA 'CAÇA GROSSA' NA ÁFRICA COLONIAL}

Em 1900, foi realizada a International Conference for the Preservation of the Wild Animals, Birds and Fishes of the African Continent em Londres. Entre os representantes de cada império, muitos naturalistas e amadores da caça esportiva. Do lado alemão, particparam dois exploradores e amadores da caça esportiva: Carl Georg Schillings e Hermann von Wissmann. O primeiro foi caçador, naturalista e um dos principais nomes do preservacionismo na África Oriental Alemã. O segundo foi comissário imperial e primeiro governador da África Oriental Alemã, quando introduziu a primeira ordenança de caça (1896). Passados dez anos, a política de proteção à vida selvagem de Wissmann foi elogiada no semanário londrino Saturday Review e considerada exemplar para as colônias britânicas em matéria de preservação da fauna. ${ }^{10}$

Mas a ordenança de caça que passou a vigorar na África Oriental Alemã em 1908 não acolheu os mesmos elogios. Considerada um retrocesso, ela foi alvo de muitas críticas de um grupo de amadores da caça esportiva e de naturalistas. Devido à nova ordenança, o governador Rechenberg foi acusado de favorecer a caça comercial e, por conseguinte, de promover a matança dos grandes animais da África Oriental Alemã.

Ainda em 1908, o eminente bacteriologista e prêmio Nobel de medicina, Dr. Robert Koch propôs o extermínio de algumas espécies de animais para erradicar a doença-do-sono da África oriental. ${ }^{11}$ Também na África sob domínio britânico houve controvérsia sobre os riscos que representavam certos animais selvagens como elos intermediários no ciclo da doença-do-sono para a pecuária e a saúde humana. ${ }^{12} \mathrm{O}$ eminente pesquisador inglês Sir David Bruce, diretor da Royal Society's Sleeping Sickness Commission, chegou a afirmar que a vida selvagem deveria ser sacrificada em prol da civilização. ${ }^{13}$ Aliás, Dr. Livingstone já havia comentado que a doença-do-sono seria erradicada com a marcha civilizatória sobre a natureza selvagem..$^{14}$

Na Alemanha, a solução radical de extermínio da "caça grossa" na África oriental foi tratada já em abril de 1908, durante a reunião da Associação Geral dos Caçadores Alemães (Allgemeine Deutsche Jägerschutzverein), realizada em Berlim. A notícia se espalhou pelas colônias alemãs na África. Sob o título Wildschutz in deutschen Kolonien, uma matéria foi publicada no jornal de Swakopmund, tratando da posição dos caçadores em relação à proposta de extermínio da 'caça grossa'. ${ }^{15}$ Além dos membros de associações de caça e da nobreza alemã, como o duque Victor von Ratibor, membros do meio científico 
alemão, como o Prof. Matschie e o Dr. Sander, discordaram dos argumentos do Dr. Koch. Ainda segundo a matéria da Deutsche-Südwestafrikanische Zeitung, Fritz Bley, o redator da Comissão para melhoria da proteção da vida selvagem na África alemã (Kommission für Besserung des Wildschutzes in DeutschAfrika) lembrou os alemães de sua dupla responsabilidade no continente africano: a colonização da África e a conservação do seu reino animal. A matéria foi encerrada com a seguinte ressalva: a tarefa da ciência é buscar um meio direto de acabar com a mosca tsé-tsé e, por conseguinte, com a doençado-sono, mas não um meio indireto que leve ao extermínio da vida selvagem.

Os estudos de parasitologia tropical eram ainda incipientes no início do século XX e médicos bacteriologistas, veterinários e sanitaristas tentavam a cura para doenças tropicais como a malária, a doença-do-sono e outras. No caso da doença-do-sono, o isolamento dos doentes foi uma das alternativas de prevenção e tratamento.

Mas houve medida mais radical. Em 1910, o governo da África Oriental Alemã tentou fazer um 'cinturão sanitário' para isolar os rebanhos de uma eventual peste bovina, supostamente detectada na vizinha África Oriental Britânica. ${ }^{16}$ A criação de um 'cinturão de saneamento' de aproximadamente $400 \mathrm{~km}$ de cumprimento por $50 \mathrm{~km}$ de largura nas cercanias do Kilimanjaro foi uma 'medida de extermínio' (Ausrottungsmassnahme) cuja realização durou quase um mês, sendo abatidas dezenas de milhares de animais selvagens de mais de 20 espécies, segundo Carl G. Schillings. ${ }^{17}$

A mobilização em prol da vida selvagem tanto na imprensa alemã quanto no círculo da corte imperial em Berlim foi fundamental para impedir que o governador Rechenberg ordenasse uma segunda matança de milhares de animais selvagens quando houve suspeita de peste bovina, na vizinha Uganda, em meados de 1911.18 Cabe ressaltar que tal medida política teve amparo científico, mas tanto os argumentos de Koch quanto a decisão de extermínio de Rechemberg foram criticadas por amadores da caça esportiva como Carl Georg Schillings e Hans Paasche, bem como por naturalistas como Fritz Behn, Paul Matschie e Paul Sarasin. ${ }^{19}$

Na África Central Britânica houve também matança, mas em menor escala. Em 1912, num jornal da África do Sudoeste Alemã (atual Namíbia), uma matéria informou sobre uma matança na Nyassalândia (atual Malawi). O governo britânico havia escolhido uma área de 10 milhas quadradas, habitada por nativos, com rica fauna e muita glossina morsitans. Nesta área foi ordenada, então, o abate de animais selvagens, com poucas exceções. Com isso, segundo a matéria, esperava-se melhor compreender a correlação entre animais selvagens e a mosca tsé-tsé no ciclo da doença-do-sono. ${ }^{20}$ 


\section{MATANÇA DA 'CAÇA GROSSA’ EM MOÇAMBIQUE}

Passadas algumas décadas da polêmica em torno da proposta de Robert Koch em exterminar os animais de "caça grossa" e da matança na Nyassalândia, o veterinário Dr. Nuno José Gago da Câmara escreveu um artigo sobre a caça em Moçambique, no qual ele defendeu o isolamento de animais selvagens numa grande reserva de caça e o extermínio de todos os mamíferos selvagens existentes fora dessa reserva. ${ }^{21}$

Quando publicou seu artigo em prol do extermínio de todos os mamíferos fora da reserva, o Dr. Nuno José Gago da Câmara já tinha larga experiência em parasitologia tropical, pois, em 1928, já era assistente do Laboratório do Huambo, do qual veio depois a ser o primeiro Diretor. Em 1930, foi autor de um pequeno estudo sobre a raiva em Angola, no qual apresentava, pela primeira vez, um diagnóstico da virose naquela colônia. Um segundo trabalho foi publicado em 1932, vindo a ser referência sobre a peste suína em Angola. ${ }^{22}$ Em 1934, deixou Angola para assumir a Direção do Laboratório Central de Patologia Veterinária de Moçambique. ${ }^{23}$

Para o Dr. Câmara, "a erradicação das doenças do gado devida a carraças seria muito simples e rápida onde não houvesse caça alguma". Segundo ele, "nas doenças do gado provocadas por endo-parasitas, a caça é incontestável auxiliar da sua propagação quando se dessedenta e pasta nos mesmos bebedouros e prados que as espécies pecuárias. ${ }^{24}$

Nota-se que o médico-veterinário não era nada simpático à caça, sobretudo porque o "nefasto papel da caça toma quase sempre graves proporções ao tratar-se das doenças devidas a vírus." Para o Dr. Câmara, havia ainda o risco de contágio no caso de doenças do gado de origem bacteriana, pois "o contato ou a aproximação da caça nas zonas pecuárias é condição ótima de recíproco contágio.”25

No supracitado artigo do Dr. Câmara, as referências à relação entre doenças do gado e de animais selvagens na África do Sul, Quênia, Uganda e Tanganica acusam a circulação de informações no meio científico colonial. Também circulou nos espaços coloniais de diferentes impérios uma antipatia (provavelmente recíproca) entre "progressistas" e "preservacionistas". O Dr. Câmara chegou a considerar "comodismo anti-progressivo" a posição em prol de reservas de caça. Segundo ele, mais inteligente seria pensar em criar "reservas de bovinos" no lugar de "reservas de caça". Pareceu-lhe indiscutível o "alcance civilizador e econômico" que envolveria tal ideia. ${ }^{26}$

Ainda contra a caça, o médico veterinário informou que, no orçamento oficial de Moçambique, as receitas advindas da caça eram praticamente absorvidas pelas despesas normais de vencimentos e de consumo inerentes às 
comissões de caça. Afirmou ainda não haver saldos suficientes para devidamente manter e convenientemente defender as cinco reservas oficiais de caça. ${ }^{27}$

Assim, considerou que "a existência da caça acarreta tão graves males e tão grandes prejuízos que perante eles a sua utilidade fica perfeitamente apagada." Asseverou que "a existência da caça só verdadeiramente interessa aos caçadores e aos naturalistas" e "a sanidade humana e a economia agropecuária de um território inteiro não devem ser sacrificadas ao interesse de uma tão pequena minoria, fundamentado em argumentos tão frágeis. ${ }^{28}$

No entanto, o Dr. Câmara reconheceu que, "por determinados motivos científicos, por certas conveniências de turismo, ou pelas obrigações de acordos internacionais", forçoso era dar uma proteção oficial à caça. Mas "para poder harmonizar a necessidade de extermínio dos animais bravios com a condescendência da conservação da caça", sugeriu "a constituição de uma grande reserva nacional de caça em condições ótimas de habitat para todas as espécies selvagens, isolando-a absolutamente do meio exterior, e mantendo-a sob permanente fiscalização sanitária interna" e "o extermínio de todos os mamíferos selvagens existentes fora dessa reserva". ${ }^{29}$

No radicalismo do Dr. Câmara se percebe um eco daquela proposta polêmica do Dr. Koch. Mas assim como outros médicos e zoólogos alemães discordaram dos argumentos do eminente compatriota, também o radicalismo do veterinário português encontrou resistência entre seus pares. Dois anos antes da publicação do artigo polêmico do Dr. Câmara, o veterinário José Leitão ponderava a relação entre a caça e o problema parasitário. ${ }^{30}$ Dez anos depois, Antonio Pegado ainda abordou o assunto. ${ }^{31}$ Nas décadas de 1950 e 60, outros artigos trataram de zoonoses com relação à caça e à pecuária. ${ }^{32}$ Alguns deles ainda defendiam a matança da "caça grossa" em prol da civilização. ${ }^{33}$

E não seria de estranhar o apoio intelectual de Gilberto Freyre a certas atividades das autoridades portuguesas contra as doenças tropicais, sobretudo contra a doença-do-sono. Em sua viagem pela África a convite do governo Salazar, Gilberto Freyre fez o seguinte comentário.

A só presença dessa mosca terrível mostra o que tem de ser o esforço português na Guiné contra uma natureza aparentemente idílica, mas na verdade traiçoeira. Tão traiçoeira que protege com seu verde tropical moscas e mosquitos mortíferos, onças e hienas, crocodilos e hipopótamos, vermes e cobras que são ainda uma legião de demônios a danarem a vida humana nesta região. A vida, o trabalho, a lavoura, a colonização, principalmente européia e principalmente cristã. ${ }^{34}$ 
Escusado lembrar que o sociólogo brasileiro visitou o Laboratório Central de Patologia Veterinária nos arredores de Nova Lisboa e outras instituições e estações agropecuárias não apenas em Angola, mas também em Guiné, Cabo Verde e Moçambique. Gilberto Freyre fez vários elogios aos agrônomos, zootécnicos e veterinários portugueses pelos resultados obtidos no campo da agricultura e da pecuária tropical. "São homens, estes agrônomos, estes veterinários, estes zootécnicos portugueses desgarrados na África como se fossem missionários com ardente vocação para o sacrifício, que os brasileiros poderia tomar para exemplos. ${ }^{35}$ Ver-se-á a seguir que alguns desses homens desempenharam o papel de "missionários com ardente vocação para o sacrifício", mas não sacrifício de si mesmos, porém de milhares de animais selvagens.

No que tange ainda à parasitologia tropical e às suas implicações para a pecuária e a saúde humana na África portuguesa, é possível que Gilberto Freyre não tenha se inteirado sobre certas polêmicas que envolviam médicos e veterinários portugueses, como, por exemplo, aquela em torno do abate da 'caça grossa' em prol da pecuária tropical.

O problema não era apenas a diatribe envolvendo veterinários e amadores da caça esportiva sobre o abate da fauna bravia, mas sim a ocorrência de uma matança executada pelas brigadas de caça da Missão de Combate às Tripanossomíases (MCT). Por isso, o assunto ainda era motivo de polêmica no início da década de 1970.

Depois de muitos anos atuando na divisão de veterinária da MCT, Jaime Augusto Travassos Santos Dias e Armando José Rosinha decidiram abandonar a MCT. ${ }^{36}$ Durante as VII Jornadas médico-veterinárias, realizadas em Lourenço Marques, de 26 de Setembro a 2 de Outubro de 1971, os dois veterinários apresentaram um trabalho que foi publicado em diversos periódicos científicos. ${ }^{37}$ Tratou-se de um balanço sobre a matança da 'caça grossa' promovida pela MCT. ${ }^{38}$

Segundo dados coligidos pelos dois veterinários da MCT, foram abatidos em torno de 230.000 mamíferos (elefantes, rinocerontes, hipopótamos, búfalos, zebras, gazelas e antílopes...) entre 1947 e 1969. ${ }^{39}$ Para os veterinários Dias e Rosinha, o problema não era o abate em si, mas as formas como ele estava sendo realizado, "desafiando as mais rudimentares regras do verdadeiro espírito científico, sem que de tal facto tivessem resultado consideráveis alterações nas comunidades glossínicas cuja destruição se visava". ${ }^{40}$ Assim, os médicos veterinários concluíam o artigo, afirmando que o abate da forma como estava sendo conduzido em Moçambique não podia continuar. Ressaltaram ainda os autores que "a fauna bravia da África representa um valor muitas vezes insubstituível (por razões de ordem científica, estética, cultural, ecológica e 
econômica) e, como tal, digna de ser preservada dos entusiasmos, das fúrias e da ignorância de muitos." ${ }^{41}$

\section{EM PROL DAS ÁREAS DE PRESERVAÇÃO DA VIDA SELVAGEM}

A polêmica em torno da extinção dos grandes animais esteve associada à formação de reservas, inclusive para a caça esportiva. Porém, alguns achavam que tais reservas preservariam também as doenças tropicais..$^{42}$ Em 17 de agosto de 1912, o jornal de Lüderitzbucht publicou uma matéria sobre a relação entre animais selvagens e a doença-do-sono. ${ }^{43} \mathrm{~A}$ matéria tratou da posição do conde Zech, amador da caça esportiva e ex-governador da colônia do Togo, sobre o papel da "caça grossa" como elo intermediário da doença-do-sono. Apesar da controvérsia existente, áreas antropizadas pela colonização, inclusive aquelas com atividades pecuárias, deveriam ser protegidas, sendo a caça um meio de proteção do gado e dos colonos contra a doença-do-sono. Neste caso, reservas de proteção à vida selvagem deveriam ser criadas para encerram a fauna nativa. Sua localização deveria ser afastada dos núcleos coloniais ou de atividades agropastoris. Enfim, o espaço colonial era dicotomizado: áreas de glossinias e animais selvagens versus áreas de humanos e animais domésticos. ${ }^{44}$

Em Moçambique, autoridades veterinárias que trataram do problema parasitário, tanto na caça quanto no gado, se envolveram, igualmente, em propostas de criação de reservas para a vida selvagem. ${ }^{45}$ Alguns também fizeram diagnósticos dos problemas à proteção da vida selvagem e propostas para proteger a fauna, considerada patrimônio. ${ }^{46}$

Escusado lembrar que o preservacionismo num contexto colonial também reproduzia certas relações de poder, nas quais os 'caçadores tradicionais' eram sancionados pela normatização da caça esportiva que também simbolizava uma apropriação exclusivista das reservas de caça. ${ }^{47}$

Além de veterinários, alguns amadores da caça esportiva também se envolveram com a causa preservacionista em Moçambique, como o português Alfredo Rodrigues, que chegou em 1927, para servir ao Exército. Fez parte da guarnição de Nampula. Foi nomeado fiscal do Parque Nacional de Gorongosa em 1948. No entanto, "foi sempre caçador impetuoso, que trilhou florestas e abateu feras sem conta" ${ }^{48}$ A reserva do Parque de Gorongosa foi criada pela Ordem 4178, de 2 de março de 1921, do então Governo da Companhia de Moçambique. Sua área inicial era de $1.000 \mathrm{~km}^{2}$. Em 1935, ela foi aumentada para cerca de $3.200 \mathrm{~km}^{2}{ }^{29}$ Inicialmente, ela foi uma reserva de caça da Companhia de Moçambique para os administradores da companhia e seus visitantes. Nota-se, portanto, a privatização de um espaço colonial para a caça esportiva cuja prática era um privilégio..$^{50}$ Isso permite inferir que o impacto nos círculos imperiais da criação do Parque Nacional de Yellowstone, nos 
EUA, em 1872, e sua influência na criação dos primeiros parques e reservas na África colonial não implicou em democratizar esses patrimônios naturais..$^{51}$

Na década de 1930 foi criada também a Reserva Especial de Maputo (REM). ${ }^{52}$ Assim como em outras reservas de Moçambique e Angola, à fauna nativa foram introduzidos animais vindos de países vizinhos como África do Sul e Kênia. ${ }^{53}$

Em Angola, na província do Bengo, a reserva de caça de Quiçama foi criada em 1938 e se tornou Parque Nacional em 1957. Sua área total perfaz quase $10.000 \mathrm{~km}^{2}$. Entre os proponentes das reservas de caça em Angola, encontramse alguns amadores da caça esportiva como o coronel Antonio Brandão de Melo. ${ }^{54} \mathrm{Na}$ primeira metade do século XX, a caça esportiva era praticada em Angola, mas sem impacto econômico. Um estudo comparativo das leis de caça acusa uma realidade similar entre as colônias portuguesas. ${ }^{55}$ Comparada com a literatura em inglês sobre caça na África colonial, pouquíssimas foram os artigos nas décadas de 30 e 40 sobre a caça em Angola. ${ }^{56}$

A partir dos meados do século XX surge um interesse em desenvolver o turismo e a caça esportiva como ocorria na África do Sul e na África Oriental ainda sob domínio britânico. ${ }^{57}$ A nascente indústria dos safáris, especialmente em Moçambique, foi um filão não apenas para caçadores desportistas como também para aqueles profissionais. ${ }^{58}$

Em 1952, foi realizado o IV Congresso de Turismo Africano em Lourenço Marques. A caça em Moçambique foi tema de um livro, organizado pela Comissão de Caça da Colônia. Em suas 70 páginas, uma série de ilustrações e textos demonstra as potencialidades faunísticas do território. O livro também foi editado em inglês, o que acusa o interesse num público específico, os vizinhos bôeres e ingleses. ${ }^{59}$ No mesmo ano, um pequeno artigo destacou Moçambique como um paraíso da caça (ou dos caçadores?). ${ }^{60}$ Ainda na década de 1950 foi publicado o livro Animais selvagens, do caçador e fotógrafo João Augusto da Silva. ${ }^{61}$ Nas décadas de 1960 e 70, o potencial turístico de parques e reservas de Moçambique e Angola foi assunto de várias publicações. ${ }^{62}$

Menos conhecido foi o trabalho de Sísifo do Serviço de Veterinária de Moçambique na domesticação de animais selvagens, inclusive de elefantes. ${ }^{63}$ O Prof. Dr. Jaime Augusto Travassos Santos Dias considerava um trabalho promissor amansar algumas espécies da fauna bravia, tanto para transporte (como a zebra), para tração em trabalhos agrícolas com a charrua (como o elande) e para alimentação (como o avestruz) quanto para o avanço da zoologia, "permitindo um estudo mais completo das doenças que lhes são próprias e das comuns a eles e às espécies domésticas, em que as tripanossomíases ocupariam ainda o maior lugar." ${ }^{64}$

No relatório anual dos Serviços de Veterinária de 1933 tem-se a informação que "a necessidade econômica de utilizar o animal como máquina 
agrícola nas regiões infectadas de tripanossomíase levou o Governo a tentar a domesticação de espécies selvagens que se presumem ser tolerantes a esta zoonose e que pela sua corpulência, conformação e índole sejam capazes de produzir trabalho ou, para melhor dizer, prestar serviço à agricultura." ${ }_{65}$

A domesticação de animais selvagens para fins econômicos ainda era um objetivo do Conselho de Proteção da Natureza, órgão criado em 1955 pelo Decreto n. 40040, no qual se diz que "o conjunto de previdências a tomar relativamente à fauna bravia destina-se "a conservá-la como elemento de equilíbrio bioecológico e a desenvolvê-la para utilidade do homem." Pelo mesmo decreto, o Serviço de Veterinária deve "promover o estabelecimento de estações experimentais de domesticação e hibridação de animais selvagens."66

O interesse do Prof. Dr. Santos pela domesticação de animais selvagens tinha também a meta de gerar "incontestável benefício para a economia". ${ }^{67}$ Mas poderia ser também a alternativa para algumas espécies da fauna bravia que estavam sendo abatidas pelas brigadas de caça da MCT. É nesse sentido que o veterinário sugeria um recinto de 100 hectares "convenientemente situado" para abrigar os animais capturados, os quais, posteriormente, deveriam se adaptar e ser amansados. ${ }^{68}$

Em 1965, outro veterinário, Dr. Armando José Rosinha, assumiu a direção do Parque Nacional da Gorongosa ${ }^{6}$ Cabe lembrar que muitos médicos e veterinários portugueses como Nuno J. G. da Câmara e Armando José Rosinha viveram parte de suas vidas em Angola e Moçambique. Nesse sentido, as primeiras reservas de caça e parques de proteção à vida selvagem das décadas de 20 e 30 coincidiram com a fundação de centros e laboratório de veterinária e patologia tropical e com a consolidação de uma rede técnico-científica no espaço colonial por onde circularam especialistas portugueses, especialmente entre Angola e Moçambique..$^{70}$ Isso permitiu uma troca transcolonial de experiências e uma consciência preservacionista em relação à fauna e à flora nativas.

Em 1972, o Dr. Armando José Rosinha (Chefe dos Serviços de Fauna Bravia), o Prof. Dr. Jaime Augusto Travassos Dias (Diretor da Faculdade de Veterinária) e o Dr. Fernando Cardoso Paisana (Diretor dos Serviços de Veterinária) participaram da $1^{\mathrm{a}}$ Reunião Nacional para o estudo dos problemas da fauna selvagem e proteção da Natureza no ultramar português, realizada em Sá da Bandeira, em Angola. No mesmo ano, o professor Jaime A. T. S. Dias publica um pequeno artigo ressaltando a urgência do preservacionismo no espaço colonial. ${ }^{72}$

Além de poucos veterinários e zootécnicos, alguns amadores da caça esportiva estiveram entre os primeiros a promover o preservacionismo em Angola e Moçambique. Alguns amadores da caça esportiva trocaram os rifles pelas câmaras. Na África Oriental das primeiras décadas do século XX, Carl Georg Schillings e Hans Schomburgk foram pioneiros. Carl Georg Schillings 
era caçador e comercializou espécies (vivas e mortas) para museus de história natural e parques zoológicos. Como fotógrafo fez as primeiras imagens de animais selvagens em seu próprio habitat. Também fez as primeiras fotografias noturnas da vida selvagem. ${ }^{72}$ Natural de Hamburgo, Hans Schomburgk foi para a África do Sul em 1898. Realizou várias expedições de exploração e caça pela África, inclusive no sul de Angola. Comercializou animas selvagens para a Europa, inclusive para o Tierpark de Carl Hagenbeck. Em 1909, conseguiu levar os primeiros elefantes da África oriental para a Europa. Mas foi como escritor e produtor de filmes sobre a vida selvagem que Schomburgk deu sua melhor contribuição ao preservacionismo. ${ }^{73}$

Schillings e Schomburgk foram exemplos de caçadores que passaram a valorizar as imagens de animais vivos e não mais aquelas das feras abatidas aos pés do caçador ou aquelas do animal morto como troféu de caça. A substituição do rifle pela câmara fotográfica inaugurou uma nova forma de apreciação da paisagem selvagem imprescindível à passagem do caçador em turista, da reserva de caça em parques de proteção à vida selvagem. Para Moçambique, os amadores da caça esportiva e fotógrafos João Augusto Silva e M. Cunha foram, talvez, os primeiros a enfatizar a "captura de imagens" de animais selvagens a partir da década de $1960 .{ }^{74} \mathrm{O}$ caçador brasileiro Jorge Alves de Lima foi, igualmente, um "capturador de imagens" na África austral e oriental. ${ }^{75}$

Nas últimas décadas do colonialismo em Moçambique, entre os amadores da caça esportiva e prosélitos do preservacionismo, se encontravam os portugueses Celestino Gonçalves e José da Cunha Pardal. O primeiro chegou em Moçambique em 1952 e, cinco anos depois, já era fiscal de caça dos quadros da Comissão Central de Caça. Por quase quarenta anos trabalhou a serviço da proteção da fauna bravia em órgãos e instituições coloniais e pós-coloniais. ${ }^{76}$ O segundo foi exímio caçador de elefantes e assumiu funções em serviços de proteção à vida selvagem, como a Comissão Central de Caça e o Conselho de Proteção da Natureza. ${ }^{77}$

Nota-se que a relação entre caça esportiva e preservacionismo na África do Sul, na África Oriental Britânica e na África Oriental Alemã teve também efeitos correlatos em Angola e Moçambique em décadas posteriores. Aliás, foi na África Oriental Portuguesa que Gilberto Freyre pôde realizar seu sonho de menino e ver leões, zebras, búfalos, hipopótamos, elefantes e muito mais em seu próprio habitat natural. ${ }^{78}$ Alguns anos depois da visita do ilustre pernambucano foi a vez do presidente português Francisco Craveiro Lopes provar da mesma sensação no parque da Gorongosa, onde o anfitrião era o ex-combatente e caçador desportista Alfredo Rodrigues. ${ }^{79}$ 


\section{CONSIDERAÇÕES FINAIS}

Em 1947, em artigo publicado no Boletim Geral das Colônias, o veterinário Dr. Nuno J. Gago da Câmara defendia o extermínio dos animais selvagens tal como fez o bacteriologista alemão Dr. Robert Koch no início do século. Assim como o Prof. Paul Matschie e o Dr. Sander discordaram do radicalismo do ilustre compatriota, outros veterinários portugueses tiveram posições diferentes daquela do Dr. Câmara. Entre eles, destacaram-se Jaime Travassos Santos Dias e Armando José Rosinha.

Como alguns amadores da caça esportiva, os cientistas também se envolveram em propostas de criação de áreas para proteção da vida selvagem. $\mathrm{Na}$ África Oriental Alemã, Carl Geog Schillings e Hans Schomburgk militaram por reservas e parques de proteção à vida selvagem. Eles também se envolveram na organização de safáris e na produção de imagens da vida selvagem. Meio século depois, outros caçadores e fotógrafos destacaram o prazer em capturar imagens do reino animal em Moçambique. Diferentes das fotografias de José Rufino Santos de feras enjauladas no parque zoológico de Lourenço Marques da Belle Époque, as fotografias de animais selvagens em seu próprio habitat se inserem numa revalorização da paisagem selvagem, não mais como um espaço colonial a ser urbanizado ou ruralizado, mas simplesmente para ser protegido e preservado.

A circulação de práticas como a caça esportiva em colônias como Angola e Moçambique não devem ser analisadas somente sob o prisma imperial. A troca de experiências também se deu entre as colônias de diferentes impérios. Para o caso da caça esportiva em Angola e Moçambique, as influências não apenas dos ingleses, mas também dos bôeres e dos alemães foram pouco estudadas quando não estigmatizadas..$^{80} \mathrm{O}$ historiador deve atentar para a simultaneidade e a defasagem dessas influências, pois a circulação de ideias e experiências podem ocorrem em dois tempos: um sincrônico, outro diacrônico.

Se Angola e Moçambique foram territórios de caça para os portugueses e também para os vizinhos ingleses e bôeres, isso pode acusar uma defasagem em termos de regulamentação da caça. Afinal, o rigor da legislação de controle da caça na África colonial sob domínio britânico e alemão tornou as colônias portuguesas preferidas não só para a caça esportiva como também para a caça comercial. Escusado lembrar que, embora representantes de Portugal e Alemanha tivessem participado da primeira International Conference on the Preservation of Wild Animals, Birds and Fish in Africa, realizada em Londres em maio de 1900, ambos os países não retificaram a convenção que propunha uma política 'trans-imperial' para a preservação da vida selvagem no continente africano. 
A proposta desse trabalho foi demonstrar como a caça esportiva enquanto parte de um habitus colonial foi importante para a emergência de uma consciência ambiental 'trans-imperial' nas primeiras décadas do século XX, quando entram em risco de extinção várias espécies animais na África, especialmente em zonas sob domínio britânico, alemão e português. Uma futura pesquisa poderá tratar das influências das ordenanças e demais regulamentos imperiais para a caça esportiva e de controle e repressão da caça comercial do mundo "anglo-germânico" sobre as incipientes políticas de preservação da vida selvagem no "mundo luso-tropical" das primeiras décadas do século XX.

Por último, cabe lembrar que, em meados do século $\mathrm{XX}$, quando viajou a convite do governo Salazar para algumas colônias do império português, Gilberto Freyre relatou algumas supostas influências inglesas em Angola e Moçambique. Poucas delas, como o gosto pelos desportos e os jardins e parques em Lourenço Marques, seriam positivas na avaliação do mestre de Apipucos. Em seu luso-tropicalismo, tais anglicismos deveriam ser assimilados. ${ }^{81}$ Porém, um dos limites do "luso-tropicalismo metodológico" é o seu approach assimilacionista. Nessa perspectiva, o que não é assimilável das culturas alienígenas se torna irremediavelmente uma ameaça. Mas a história da saúde e a dos esportes na África colonial permitem novas abordagens teórico-metodológicas, nas quais a circulação de ideias e experiências nos espaços coloniais entre diferentes impérios tem demonstrado a pertinência de conectar aquilo que certas ideologias separaram ou simplesmente ignoraram ou subestimaram.

\section{NOTAS}

I $O$ presente trabalho é resultado de um projeto de pesquisa em andamento com Bolsa Produtividade do CNPq, com interface à pesquisa Germânias Tropicais, realizada junto ao Laboratório de Imigração e História Ambiental (www.labimha.ufsc.br) com auxílio financeiro do CNPq. Um especial agradecimento ao historiador Marcos Vinícius Santos Dias Coelho pela disponibilidade, durante a sua estada em Moçambique, em localizar e enviar material imprescindível à pesquisa e à versão final desse artigo. Uma versão preliminar foi apresentada no XI Congresso Luso Afro Brasileiro de Ciências Sociais, realizado em Salvador entre os dias 7 e 10 de agosto de 2011 .

2 SINGARAVÉLOU, Pierre; SOREZ, Julien. Pour une histoire transnationale du sport. Circulations des pratiques sportives en situations impériales. In: SINGARAVÉLOU, P.; SOREZ, J. (sous la dir.) L'Empire des Sports. Une histoire de la mondialisation culturelle. Paris: Belin. p. 40.

3 Para Moçambique do período colonial há copiosa literatura sobre o assunto. Por exemplo, NEVES, Diocleciano F. Itinerário de uma viagem à caça dos elephantes. Lisboa : Typographia Universal, I878; RODRIGUES, P. Viana. Relatório duma caçada aos elefantes na circunscrição do Maputo apresentado a S. Exa. o Governador Geral Dr. Álvaro de Castro. Lourenço Marques : Imprensa Nacional, 1917; VASCONCELOS, João Teixeira de. Memórias de um caçador de elefantes. Porto: Edição de Maranus, 1924. 
Caça e preservação da vida selvagem na África colonial

4 Durante sua estada em Angola, Gilberto Freyre fez observação acurada sobre os novos amadores da caça esportiva. "[...] Regiões perto daquelas a que vêm caçar feras de grande porte europeus também portentosos que se dão a este esporte, hoje menos de fidalgos que de novo-ricos." FREYRE, Gilberto. Aventura e Rotina. Sugestões de uma viagem à procura das constantes portuguesas de caráter e ação. Rio de Janeiro: Topbooks Editora, ( ${ }^{\text {a }}$ ed. 1953), 200 I. p. 372.

5 ○ esporte como forma de emulação foi tratado en passant por A. Guttmann em seu prefácio ao livro L'empire des sports, op. cit, 2010.

6 WÄCHTER, Jürgen. Naturschutz in den deutschen Kolonie in Afrika ( 884 - 19 | 8). Berlin: Lit Verlag, 2008, p. 29-30.

7 Sobre a estigmatização do caçador boer, ver WÄCHTER, op cit., p. 25.

8 Na historiografia inglesa foi destacada ainda a relação da caça esportiva nas colônias britânicas com valores de masculinidade, especialmente ligados a um conjunto marcial de práticas e saberes. MANGAN, J. A.; MCKENZIE, Callum. "Blooding the Martial Male: the Imperial Officier, Field Sports and Big Game Hunting" (Special Issue) The International Journal of the History of Sport (IJHS), 25, 9 , 2008, p. $1080-1105$.

9 Sobre essa literatura em língua inglesa, ver MACKENZIE, John. The Empire of Nature: Hunting, Conservation and British imperialim. Manchester and New York: Manchester University Press, 1988; MACKENZIE, J. "Hunting and Juvenile Literature", in RICHARDS, Jeffrey (ed). Imperialism and Juvenile Literature. Manchester: Manchester University Press, 1988, p. |44-172. Em língua portuguesa, ver: GALVÃO, Henrique. A caça no império português. Porto: Primeiro de Janeiro, 1945; TORRES, Nuno de. Da caça em África. In: O Mundo Português. vol. 12, no 139 (1945), p. 297-302; DELMONT, José. O desporto das grandes emoções. Porto : Livraria Tavares Martins, 1954.

${ }^{10}$ GISSBIBL, Bernhard. German Colonialism an the Beginnings of the International Wildlife Preservation in Africa. German Historical Institut, London, Bulletin Supplement, 3 (2006), p. I2I.

I $\mathrm{KOCH}$, Robert. Über meine Schlafkrankheits-Expedition. Vortrag gehalten in der Abteilung BerlinCharlottenburg der Deutschen Kolonialgesellschaft, Berlin: Dietrich Reimer, 1908.

12 BUTLER, A. L. Big Game Preservation and the Sleeping Sickness; Spectator, 100:4161 (28.03. 1908) p. 496. MACKENZIE, J. M. Experts and amateurs: tsetse, nagana and sleeping sickness in East and Central Africa, in MACKENZIE, J. (dir.) Imperialism and the Natural World, Manchester: Manchester University Press, 1990, p. 187-212.

13 “Ein Naturschutzpark in unseren Kolonien”. Lüderitzbuchter Zeitung. Lüderitzbucht, (03/04/I9|4).

14 MACKENZIE, J. M. The Empire of Nature - Hunting, Conservation and British Imperialism. Manchester, Manchester University Press, p. 234.

15 "Wildschutz in deutschen Kolonien" Deutsch-Westafrikanische-Zeitung, Swakopmund, (30/05/1908)

${ }^{16}$ WÄCHTER, op. cit. p. 73.

17 SCHILLINGS, Carl G. "Hagenbeck als Erzieher". Deutsch-Ostafrikanische Zeitung, Dar es Salaam, (02.12.1911).

${ }^{18}$ WÄCHTER, op. cit., p. 75-76.

19 Para críticas coevas à matança sob as ordens do governador Rechenberg, ver: SCHILLINGS, Carl G. "Wildmord in Deutsch-Ostafrika", Zeitschrift des Allgemeinen Deutschen Jagdzchutz-Verbandes 
Caça e preservação da vida selvagem na África colonial

17 (32), 191 I: 378-379; BEHN, F. "Naturerhaltung und Wildmord in Deutsch-Ostafrika - ein Kulturskandal". Naturwissenschaftliche Wochenschrift, Nr. 5।, Berlin, 191 I. p. 80 I-807. MATSCHIE, P. "Die Verwüstung deutsch-ostafrikanische Wildbahnen", Zeitschrift des Allgemeinen Deutschen Jagdzchutz-Verbandes I6 (31), I9 I I: 360-36 I; SARASIN, Paul. Über nationalen und internationalen Vogelschutz, sowie einege anschliessende Frage des Weltnaturschutzes, Basel: Helbing \& Lichtenhahn, 1911 .

20 "Gouverneur Graf Zech über Wildschutz und Schlafkrankheit", Lüderitzbuchter Zeitung, Lüderitzbucht, (17/08/19/2).

${ }^{21}$ CÂMARA, Nuno J. Gago. A caça em moçambique. Boletim Geral das Colónias. Agência Geral das Colónias. No 270 - Vol. XXIII, 1947, p. I 13.

22 CÂMARA, Nuno J. G. Contribuição para o estudo da Raiva em Angola. Pecuária, 1930, p. I023; CÂMARA, Nuno J. G. História da Peste Suína em Angola. Pecuária, 1932, p. 25-40.

${ }^{23}$ MENDES, Antonio Martins. A história do Laboratório Central de Patologia Veterinária de Angola. RPCV. 97 (54I), 2002, p. 19.

${ }^{24}$ CÂMARA, op cit., p. 110.

${ }^{25}$ Idem, ibidem.

${ }^{26}$ Idem, p. ||0-।|।.

27 Idem, p. I 13.

${ }^{28}$ Idem, ibidem.

${ }^{29}$ Idem, ibidem.

30 LEITÃO, José da Silva. A caça e o problema parasitário. II Congresso da União Nacional In: Boletim geral das colónias. Ano XXI, n²4I (Julho de 1945), p. I0 I - I I I.

${ }^{3}$ PEGADO, Antonio. $\bigcirc$ problema da caça grossa e a mosca de Tsé-tsé. In: Revista d'aquém e d'além mar. - Ano V, n 60 (1955), p. 5-7.

32 VALADÃO, Francisco Garcia. A luta contra a febre aftosa e o problema da caça em Moçambique. In: Anais dos serviços de veterinária e indústria animal. n IV ( 95 I), p. 67- 72; DIAS, Jaime Augusto Travassos Santos e GONÇALVES, A. Castelo Branco. Infecciosidade por tripanossomias da caça e da tsé-tsé na região do Muda In: Anais dos Serviços de veterinária de Moçambique. n IX (I 963), p. 4 I -53; VALADÃO, Francisco Garcia. Alguns aspectos do problema da caça em relação á ocupação pecuária. In: Anais dos Serviços de veterinária de Moçambique. nº X (1966), p. 209-21 I.

33 SILVA, José Marques. Alguns aspectos do controle da Glossina M. West pelo abate da caça na região do Govuro ( sul do Save). I Congresso Nacional de Medicina Tropical - Malária In: Anais do Instituto de medicina Tropical. Vol. X, no 3 (Set. 1953), p. 925-946; AZEVEDO, J. Fraga de (et al.) Plano de trabalhos para a campanha de erradicação: $2^{\text {a }}$ fase ou fase de comabte às glossinas: $6^{\text {a }}$ secção - caça. In: O reaparecimento da glossina palpalis palpalis na ilha do Príncipe. Lisboa : Junta de Investigações do Ultramar, 1961, p. 104.

${ }^{34}$ FREYRE, op cit. p. 257-258.

35 FREYRE, op cit., p. 412.

36 Jaime Travassos Santos Dias foi professor catedrático da faculdade de veterinária da Universidade Eduardo Mondlane, diretor do Museu de História Natural e sócio fundador da Associação de Proteção da Natureza de Moçambique. Armando José Rosinha assumiu a chefia de diversos setores 
Caça e preservação da vida selvagem na África colonial

da Missão de Combate às Tripanossomíases (MCT) por uma década (1953- | 963). Exerceu também outras funções durante sua vida profissional, como delegado de sanidade pecuária e chefe dos serviços de protecção à fauna da Direção Nacional de Veterinária de Lourenço Marques.

${ }^{37}$ DIAS, Jaime Augusto Travassos Santos; ROSINHA, José Armando. Terão justificação os abates indiscriminados da caça como medida de luta contra a mosaca Tsé-Tsé? Uma análise do caso de Moçambique In: Revista de Ciências Veterinárias. Série A. Vol. IV, (Dezembro 197I), p. 87-99; DIAS, Jaime Augusto Travassos Santos; ROSINHA, José Armando. Terão justificação os abates indiscriminados da caça como medida de luta contra a mosca tsé-tsé? (uma análise do caso de Moçambique) In: Anais dos Serviços de Veterinária de Moçambique. No 17-19 (1969-7I), p. 2354; DIAS, Jaime Augusto Travassos Santos; ROSINHA, José Armando. Terão justificação os abates indiscriminados da caça como medida de luta contra a mosca tsé-tsé? In: Revista agrícola. vol. XIV, No 142 (Jan. 1972), p. 22-26.

${ }^{38}$ As Missões de Combate às Tripanossomíases de Angola e Moçambique faziam parte integrante dos Serviços de Saúde e Assistência daquelas províncias com sede, respectivamente, em Luanda e em Lourenço Marques. As Missões de Combate às Tripanossomíases das províncias de Angola e Moçambique tinham como finalidades: a) O combate e profilaxia da tripanossomíase humana; b) O combate e profilaxia das tripanossomíases animais; c) A investigação científica relativa aos agentes das tripanossomíases e seus insectos vectores; d) O combate à mosca tsé-tsé para impedir a sua expansão e obter a recuperação das áreas por ela infestadas.

39 Para o relatório da MCT em Angola, ver: Missão de Combate às Tripanossomíases : relatório anual de 1966 / Serviço de Saúde e Assistência, MCT. Luanda : SSA, 1967.

${ }^{40}$ DIAS, Jaime Augusto Travassos Santos; ROSINHA, José Armando. Terão justificação os abates indiscriminados da caça como medida de luta contra a mosca tsé-tsé? (uma análise do caso de Moçambique) In: Anais dos Serviços de Veterinária de Moçambique. No I7-19 (|969-7|), p. 25.

${ }^{41}$ Idem, p. 52.

${ }^{42} \mathrm{Em}$ artigo já referido, o Dr. Nuno J. G. da Câmara trouxe exemplos da África do Sul e da Rhodésia, onde os parques nacionais representavam zonas endêmicas de várias zoonoses, o que era um problema para a pecuária nas vizinhanças das reservas de caça e parques de preservação da vida selvagem.

43 "Gouverneur Graf Zech über Wildschutz und Schlafkrankheit", Lüderitzbuchter Zeitung, Lüderitzbucht, 17/08/1912.

${ }^{44}$ Escusado lembrar que as áreas coloniais com presença antrópica ainda foram espacialmente segregadas por clivagens étnicas e sociais, inclusive com a criação de reservas para nativos ou compounds para trabalhadores nas minas, etc.

${ }^{45}$ DIAS, Jaime Augusto Travassos Santos. Proposta para a criação da "Reserva de Caça de Zinava" In: Revista de Ciências Veterinárias. Série A. - Vol. IV, (Dezembro 197I), p. 5I-65; DIAS, Jaime Augusto Travassos Santos; ROSINHA, José Armando. Proposta para a criação do "Parque Nacional do Banhine". In: Revista de Ciências Veterinárias. Série A - vol. IV (197I), p. 175- 197.

${ }^{46}$ PAISANA, Fernando Cardoso; ROSINHA, Armando J. Inventariação dos problemas relacionados com a protecção da fauna e seu aproveitamento racional. In: Anais dos Serviços de Veterinária de Moçambique. No 20/2I (1972/73), p. 15-121; DIAS, Jaime Augusto Travassos Santos; DIAS, Alexandre Herculano P.; ROSINHA, Armando J. Alguns aspectos da caça clandestina em Moçambique e sugestões para se pôr cobro a destruição do nosso património cinergético. In: Revista de Ciências Veterinárias. Série A. - Vol. IV, (Dezembro | 97I) p. I0 I-II 25. 
Caça e preservação da vida selvagem na África colonial

${ }^{47}$ ROSINHA, Armando J. O direito de caçar : quem o pode exercer e onde pode ser exercido. In: Anais dos Serviços de Veterinária de Moçambique.- no 17-19.- (1969-1971), p. 75-8I.

${ }^{48}$ Visita à reserva de caça de Gorongosa. In: Boletim geral do ultramar [Número especial dedicado à viagem de Sua Excelência o Presidente da República a Moçambique] Agência Geral do Ultramar. No 375-376 - Vol. XXXII, 1956, p. 347.

${ }^{49}$ A reserva de caça da Gorongosa. In: Boletim geral das colónias. Ano 26으. n 298 (Abril de 1950), p. $157-160$.

${ }^{50} \mathrm{Na}$ África Oriental Alemã, o governador Herrmann von Wissmann também havia proposto que a fauna fosse "caça imperial" (kaiserliches Wild) tal como em algumas reservas de caça na Alemanha. GISSBIBL, Bernhard. "German Colonialism an the Beginnings of the International Wildlife Preservation in Africa". German Historical Institut, London, Bulletin Supplement, 3 (2006), p. 127.

${ }^{51} \mathrm{O}$ historiador norte-americano R. Nash ressaltou a semelhança e diferença do Parque Nacional de Yellowstone com as reservas de caça da Europa medieval, pois o PNY era como se fosse uma reserva de um senhorio sob a forma democrática, ou seja, o soberano era a nação. Roderick Nash, "The American Invention of National Parks," American Quarterly 22 (1970): 726-735.

52 SOUSA, Antonio F. G. A reserva de caça do Maputo. In: Documentário Trimestral. № 67 (Set. 1936).

${ }_{53}$ Para o caso de Angola, o projeto Arca de Noé introduziu vários animais ao parque de Quiçama e a outras reservas. SIMÕES, Luis. Mini-operação Arca de Noé : mais uma reserva de caça na província Chimalauera. In: Revista de Angola: quinzenário ilustrado: Ano XII, nº 244 (Julho 197I). O Parque da Gorongosa também recebeu vários animais, inclusive girafas do Kênia, mas elas foram devoradas pelos leões. Sobre isso, ver: A reserva de caça da Gorongosa. In: Boletim geral das colónias. Ano 26, n² 298 (Abril de 1950), p. I57-160. A Reserva Especial de Maputo também recebeu animais dos países vizinhos. ROSINHA, Armando J. Da convivência em se valorizar a "Reserva Especial do Maputo" mediante a introdução de algumas espécies faunísticas inexistentes. In: Anais dos Serviços de Veterinária de Moçambique. n 17/19 (1969-1971), p. 63-73.

${ }^{54}$ MELO, Antonio Brandão. Criação de um Parque Nacional de Caça. Lisboa: Tipografia Cristovão Augusto Rodrigues, 1936.

${ }^{55}$ As fontes para a referida análise comparativa foram as seguintes: Regulamento para o exercicio da caça na província de Moçambique: approvado por decreto de 2 de Junho de 1909. Lourenço Marques, 1909; Lei da Caça da Guiné Portuguesa. - Lisboa : Imprensa Nacional, 1948. - 24 p., publicado no suplimento ao «Boletim Oficial» n, I0, de 7 de Julho de 1948; Regulamento da caça: Angola. Luanda : Imprensa Nacional, 1958. Ainda sobre a regulamentação da caça tem-se uma bibliografia coligida em 8 páginas: Bibliografia sobre regulamento de caça. Lisboa: Junta de Investigações Cientificas do Ultramar, 1959.

${ }^{56}$ Como exemplo, ver: CORTESÃO, Armando Zuzarte. Caçadas coloniais. In: Boletim da Sociedade Luso-Áfricana do Rio de Janeiro. - no 3 (1932), p. 27-28; ARCHER, Maria. Singularidade de um país distante: caçadas em Angola. In: Boletim da Sociedade Luso-Áfricana do Rio de Janeiro. - no 9 (1934), p. I27-I28; TERRY, Luis. Angola, reserva natural de caça. In: Revista do Ultramar. Ano I, n. ${ }^{\circ}$ 5/6 (Julho e Agosto de 1948).

${ }^{57}$ Para os domínios do império português, um levantamento das reservas de caça e sua fauna foi realizado por GALVÃO, Henrique. Fauna : mapa de distribuição das principais espécies e das reservas de protecção de caça. In: Império ultramarino português. Lisboa : Empresa Nacional de Publicidade, 1952. 
Caça e preservação da vida selvagem na África colonial

${ }^{58}$ Alguns caçadores estrangeiros como Harry Manners e Werner Alvensleben praticaram a caça profissional nas últimas décadas do colonialismo em Moçambique. Werner Alvensleben fundou a Moçambique Safarilândia. Além do caçador brasileiro Jorge Alves de Lima, o caçador José Joaquim Simões foi um dos primeiros empresários do turismo da caça em Moçambique. Sua empresa era a Simões Safaris. O caçador José Pedro Afonso Ruiz foi sócio de W. Alvensleben, mas, depois, Este último criou, depois, criou a Nyalaland Safaris. Esses caçadores gozavam de concessões de coutadas que foram abertas nas últimas décadas do colonialismo para desenvolver o turismo de caça.

${ }^{59}$ Caça em Moçambique. Porto: Litografia Nacional, 1952; Hunting in Mozambique. Porto: Litografia Nacional, 1952. Em Moçambique, outro livro já tinha sido editado em português e inglês no final da década de 1930: A caça em Moçambique. Lourenço Marques: Imprensa Nacional, 1938; Game hunting in Mozambique. Lourenço Marques: Government Printing Works, 1938.

${ }^{60}$ ANTERO, Carlos. Moçambique: paraíso da caça. In: Panorama. - No 5/6, II série (1952), s/p.

${ }^{6}$ SILVA, João Augusto. Animais selvagens. Contribuição para o estudo da fauna de Moçambique. Editora: Imprensa Nacional de Moçambique, 1956.

${ }^{62}$ Para Moçambique, ver: MARTINHO. Jacinto Pereira. A caça em Moçambique como factor de atracção turistica e fonte importante de divisas. Boletim da Sociedade de Estudos de Moçambique, 1968. p. II-14; DIAS, Jaime Augusto Travassos Santos. A caça em Moçambique e o turismo. Lourenço Marques : Sociedade de Estudos de Moçambique, 1968, p. 15-30. QUEIROZ, José Maria de Eça. Santuário bravio : os animais surpreendentes da Gorongosa e safaris em Moçambique. Lisboa : Edição do Autor, 1964. MYRE, M. Breves notas sobre protecção da natureza na província de Moçambique. Lisboa: Coimbra, 1964; Para Angola, pode-se citar os seguintes trabalhos: Turismo e reservas de caça. In: Boletim da Câmara Municipal de Sá da Bandeira . - no 18 (1965), p. 36-37; PRATTAS, Abel. A caça em Angola. In: Revista de Angola : $n^{\circ} 5$ (I ${ }^{a}$ quinzena de Abr. 1960); Caça e pesca desportiva em Angola In: Ronda pelo Ultramar, n² 2, [Dez. 1963]; PIRELLI, Mário. A fauna de Angola : descrição das espécies e subespécies dos animais de caça existentes nesta província. In: Boletim do Instituto de Angola. № 20 (Set-Dez. 1964), p. 5-44; A caça em Angola In: Revista de Angola. № I0 I, (Agosto 1965), p. 50-5 I; A caça e os caçadores In: Revista de Angola. № 98, (Junho 1965); A caça é na Província de Angola um extraordinário valor turístico. In: Revista de Angola. No 93 (Abril 1965), p. [45-47]; LAIDLEY, Fernando. A indústria de safaris em Angola In: Ronda. № 2 ( 1970); COSTA, Aleixo. A caça em Angola. In: Instituto Brasileiro da Cultura Luso-Afro-Asiática. No 4 (Ab-Jun. 1978), p. 14-19.

${ }^{63} \mathrm{Em}$ 1924, o Dr. Jacinto P. Martinho foi um grande entusiasta da domesticação de animais selvagens na Zambésia. Ainda sobre a domesticação de animais selvagens, ver: DIAS, Jaime A. T. Santos. Domesticação de animais selvagens. In: Boletim Geral do Ultramar. Ano 37, n 431 (Maio de 1961), p. 272-280.

${ }^{64}$ Idem, p. 276.

${ }^{65}$ Idem, ibidem.

${ }^{66}$ Idem, ibidem.

${ }^{67}$ Idem, p. 280.

${ }^{68}$ Idem, p. 278-279.

${ }^{69}$ Armando José Rosinha atuava desde 1950 como veterinário no Laboratório de Patologia Veterinária em Lourenço Marques. Em 1953 foi chefe do setor veterinário da Missão de Combate às Tripanossomíases (MCT) de Espungabera, na província de Manica. Juntamente com outros colegas veterinários pugnou pelo preservacionismo e se opôs ao abate indiscriminado da "caça grossa". 
Caça e preservação da vida selvagem na África colonial

70 Sobre a contratação de veterinários estrangeiros e portugueses para os Serviços Veterinários de Moçambique nas primeiras décadas do século XX, ver: MENDES, Antonio M. A Criação de Serviços Pecuários em Moçambique. Revista Portuguesa de Ciências Veterinárias. Lisboa, 2003, p. 167-177.

7 DIAS, Jaime T. S. Torna-se urgente e imperioso que se faça da conservação da natureza uma palavra de ordem. In: Revista de Ciências Veterinárias. Série B. vol. 5 (Dez. 1972), p. 49I-496.

72 Para uma biografia de Schillings, ver BECKER, Manfred. Bwana Simba. Der Herr der Löwen. Düren: Hahne \& Schloemer Verlag, 2008.

73 Schomburgk publicou vários livros. Um dos primeiros foi Wild und Wilde im Herzen Afrikas. 12 Jahre Jagd- und Forschungsreisen. Berlin: Deutsche Buch-Gemeinschaft, 1926. Seus filmes também foram muitos. Um dos primeiros foi Im deutschen Sudan (1913/1917). Na década de 1930, Schomburgk assumiu um tom mais preservacionista em filmes documentários como Das letzte Paradies ( 1932 ) e Die Wildnis stirbt ( 1936). Sobre a contribuição de Schomburgk, ver ALBRECHT, Martin: Hans Schomburgk, seine Zelte in Afrika und ein Schulzoo in Pankow. In: Ulrich van der Heyden, Joachim Zeller (Hg.) „... Macht und Anteil an der Weltherrschaft." Berlin und der deutsche Kolonialismus. Unrast-Verlag. Münster 2005;WAZ, Gerlinde: Auf der Suche nach dem letzten Paradies. Der Afrikaforscher und Regisseur Hans Schomburgk. In: Hans-Michael Bock, Wolfgang Jacobsen, Jörg Schöning (Hg.) "Triviale Tropen. Exotische Reise- und Abenteuerfilme aus Deutschland 1919-1939." Hamburg: CineGraph, 1997.

74 SILVA, João Augusto. Gorongosa: experiência de um caçador de imagens. Lourenço Marques: Empresa Moderna, I964; CUNHA, M. Caçando nos tandos e florestas de Moçambique com uma máquina fotográfica/ As emoções são as mesmas mas a espingarda mortífera foi substituída pela máquina fotográfica/ Um novo tipo de caça. In: Nova. nº 9 (Dez. 1969), p. 9- 44.

${ }^{75} \mathrm{O}$ cinegrafista Geraldo Junqueira Oliveira e o caçador Jorge Alves de Lima foram responsáveis pela produção e roteiro do documentário Kirongozi, Mestre Caçador ( 1956). Em I 957, o filme recebeu o prêmio "Saci" de melhor documentário e o prêmio "Governador do Estado de São Paulo".

76 Para as informações sobre Celestino Gonçalves: http://faunabraviademocambique.blogspot.com

77 PARDAL, José C. Cambaco I. Caça Grossa em Moçambique. Lisboa: Liber Editores, 1982; PARDAL, José. Cambaco II, Lisboa: Liber Editores, 1994.

${ }^{78}$ FREYRE, op cit., p. $431-433$

79 Visita à reserva de caça de Gorongosa. In: Boletim Geral do Ultramar [Número especial dedicado à viagem de Sua Excelência o Presidente da República a Moçambique] Agência Geral do Ultramar. No 375-376 - Vol. XXXII, 1956

${ }^{80}$ Em várias passagens de Aventura e Rotina, Gilberto Freyre atribuiu um valor negativo a supostas influências dos belgas, dos ingleses, dos bôeres ou dos holandeses. "É uma influência contra a qual precisamos de estar vigilantes, todos os luso-tropicais: a influência dos nórdicos que nos afetam os hábitos e os sentimentos com a sua vizinhança ou o seu contato de povos econômica e tecnicamente poderosos." FREYRE, op cit., p. 442.

81 "O que é preciso é que o exótico seja assimilado pelo luso, como vem sendo assimilado na capital de Moçambique". FREYRE, op cit., p. 433. 